\title{
Peace, war, and happiness: Bruder Klaus as wellbeing facilitator
}

\author{
Bruno S. Frey
}

\begin{abstract}
Little is known in the scholarly literature about the effect of war and peace on happiness; but they have a large number of direct and indirect effects on happiness, difficult or impossible to capture due mainly to issues of causality and attribution. The paper concentrates on three fundamental claims regarding the effect of war and peace on happiness: 'War brings happiness'; 'People adjust to wars'; and 'The happiness of the dead is irrelevant'. An attempt is made to discuss different solutions to deal with these claims but it is made clear that each one has grave disadvantages. Bruder Klaus, whose full name was Niklaus von Flüeh, is the patron saint of Switzerland. This paper describes Bruder Klaus as a creator of peace and, based on the claims mentioned above, as a felicitator or wellbeing facilitator.
\end{abstract}

Keywords: peace, war, happiness, wellbeing, well-being, Civil War, terrorism, Bruder Klaus

\section{Introduction}

Bruder Klaus, whose full name was Niklaus von Flüe, is the patron saint of Switzerland. He was born in 1417 into a well-to-do peasant family in Flüeli, canton Obwalden, which is in the center of Switzerland. He excelled as an officer in the Zurich war (1440-44) and was a much esteemed councilor and judge in his commune. In 1467 he changed his life dramatically. With the approval of his wife, he left his family, which included several grown-up sons, and decided to live as a hermit and to lead a spiritual life.

While he is also known as a mystic who received profound visions (highly valued by Carl Gustav Jung) this paper focuses on Bruder Klaus as a creator of peace, thus acting as a facilitator to bring happiness to people.

During Klaus' time what later became the Swiss federation was still only a loose confederation of four rural and four city cantons. In 1481 a disagreement broke out among them at the Tagsatzung (General Assembly) at Stans on the question whether or not to admit two new cantons into the confederation. The conflict ran so deep that the outbreak of war became imminent. The delegates of each of the cantons could reach consensus on only one procedural issue, namely to ask the hallowed hermit Bruder Klaus for advice. The emissary came back with two pieces of advice: "Machet den zun nit zu wit" (do not extend your boundaries too far) and "Mischt Euch nicht in fremde Händel“ (do not interfere in the affairs of other communities). Above all Bruder Klaus urged the delegates: “Keep peace!” He was well aware that cooperation leads to superior outcomes compared to aggressive and conflicting behavior. To the surprise of all observers, the delegates accepted the advice of the holy man and found a solution within two hours.

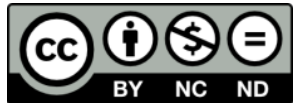

Copyright belongs to the author(s) www.internationaljournalofwellbeing.org 
This event has had a lasting effect on Swiss people. While the country unfortunately was not able to evade all conflicts and was engaged in several wars, the basic message was not lost. Over time not interfering in the affairs of other nations became a guiding rule in Swiss politics. The principle of neutrality helped to save the country from getting involved in World Wars I and II, and laid the foundation for the humanitarian efforts of the country. It made it possible for the Red Cross to emerge. The guiding principle for the efforts of the Swiss government and its diplomats still is to provide facilities, or 'good services', to achieve peace, and to guarantee peace treaties.

Many observers suggest that the stable and deep-seated democracy known in Switzerland, as well as economic prosperity and peaceful social conditions, are the major reasons why in surveys the Swiss are regularly among the top nations with respect to average happiness.

The purpose of this paper is not to provide a historical account of the manifold achievements of Bruder Klaus. Rather, he is looked at as an example of a facilitator of happiness through creating peace. The paper discusses evidence of what is known about the effect of war on happiness. The broader aspect of his teaching, that cooperation is better than conflict and leads to a happier population, is not further pursued here because it would lead too far. The author is, however, well aware that it is of great importance ${ }^{1}$.

The focus of the paper lies on the question of how much, if at all, peace raises the wellbeing of the population ${ }^{2}$. Many readers will be surprised that such a question is raised at all: is it not a matter of course that war leads to terrible human suffering and unhappiness, and that only peace allows people to achieve happiness? I started this research exactly on this premise. I was absolutely convinced that peace brings happiness, and that therefore it is a primordial goal of politics to avoid war and to achieve peace. After writing this paper I am still convinced that this is true, but I had to realize that it is not as obvious as it at first seemed to me. Things look somewhat different when one goes beyond the first (wishful) impression.

I do not want to dwell on the well-known Phoenix effect (see Organski and Kugler 1980, Koubi 2005), which suggests that a population's size and economic pace often tend to recover relatively quickly after a war, West Germany and Japan being cases in point. I wish to concentrate on the effects on happiness produced during a war, compared to periods of peace.

This paper reflects my effort to understand what is not obvious, namely that to some extent, and in some regard, war may produce happiness. I make a special effort to collect the relevant empirical evidence.

Section I reviews what is known in happiness research on the effects of war on happiness. Section II deals with the surprising claim that 'War brings happiness' by adding meaning to life, energizing the population and creating solidarity. Also, there is the phenomenon of 'combat flow' raising the happiness of the soldiers involved. Section III grapples with the observation that people tend to adapt to circumstances, in particular to war events: Over time they get used to death and destruction, and weigh them less heavily than in times of peace. Section IV considers how persons killed in war should be treated with respect to a happiness analysis. Should they be left out of account (because they are no longer among the living) or

\footnotetext{
${ }^{1}$ These considerations address issues such as the role of procedural utility (see Frey, Benz and Stutzer 2004, Frey 2008, chapter 10) and of trust (see Helliwell 2010, Helliwell and Wang 2011) for individual wellbeing.

2 Wellbeing can either be affective (a short run experience) or cognitive (a longer run evaluation of one's life, called life satisfaction). Following current practice in scientific research, I use the term happiness, or interchangeably wellbeing, for both, and differentiate the two only when it is of importance.
} 
should their unrealized expected happiness in the future be calculated? The closing section endeavors to reach conclusions. They are by necessity quite tentative and personal.

\section{Existing research on war and happiness}

The effect of war on happiness is a most relevant topic. According to credible estimates, not less than 191 million persons lost their lives due to war during the twentieth century (Iqbal 2006: 631). In addition, many millions were wounded and became disabled, suffering through the entire remainder of their lives. In addition, war destroys infrastructure as well as cultural heritage (such as a large part of ancient German cities during World War II). Even smaller wars have significant consequences. Collier (1999: 181, see also Collier and Hoeffler 2003, Murdoch and Sandler 2002) estimates that during civil wars per capita Gross Domestic Product (GDP) falls at an annual rate of $2.2 \%$ relative to a country without civil war because production directly falls and capital stock is gradually reduced. As many civil wars drag out over a considerable number of years, the decline in average income is substantial. Koubi (2005: 69), looking at a large cross-section of countries over the period 1960-89 (which does not include a major global war), finds that the average growth in GDP in countries that fought a war was slower than in those that did not, and that this effect is larger for civil than for interstate wars.

To my great surprise I could find only very few studies studying the effect of war on happiness ${ }^{3}$. In view of the great consequences of war on the population, economy and society at large this is most surprising. In comparison, there are now hundreds of studies analyzing the effects of income on happiness, generally coming to the conclusion that it is rather small, if it exists at all (see the surveys by Clark, Frijters and Shields 2008, Dolan, Peasgood and White 2008, Frey and Stutzer 2002a, 2002b, Frey 2008, Helliwell and Barrington-Leigh 2010). There may be several reasons why happiness researchers are reluctant to deal with the effect of war on happiness:

1) There is a data problem. Normally, in times of war no surveys are undertaken capturing how happy or satisfied civilians and soldiers are with their lives;

2) It is unclear whether people remember war episodes correctly. The difference between experienced and remembered utility (see Kahneman, Wakker and Sarin 1997) is crucial in this context;

3) The issue is extremely complicated. There are many different types of war, ranging from more or less dormant civil wars to all out national wars. There are also many different and indirect consequences. For example, in wars, democratic rights are curtailed and authoritarian decisions take over. Undermining democracy is known to reduce happiness (Frey and Stutzer 2000, Inglehart and Klingemann 2000, Graham and Sukhtankar 2004, Dorn et al 2005). During interstate and intrastate conflicts the health achievements of states decrease ${ }^{4}$, lowering the wellbeing of the population (Iqbal 2006). Moreover, the question of how to deal with the forgone happiness of persons dying in war is difficult to deal with;

\footnotetext{
${ }^{3}$ In contrast, the reverse causation, i.e. whether happier persons are more inclined to endorse peace, has been empirically analyzed. The important study by Diener and Tov (2007) finds that individual wellbeing is related to several peace attitudes, among them greater confidence in parliament and civil services, stronger endorsement of democracy, and less intolerance of immigrants and members of different racial and ethnic groups. These attitudes support a peaceful society that is open and free to all people. Subjective wellbeing is therefore considered "a crucial element in sustaining peace over time" (p. 438).

${ }^{4}$ Remember the influenza which broke out during WWI, killing more people than were killed in combat; and other epidemics or famines, or the effect of lack of clean water, or poor sanitation etc. prevalent during wars.
} 
4) The causalities going from war to happiness, and from happiness to war, are difficult to separate and to empirically measure.

I could find three areas in which serious empirical studies have been undertaken in order to capture the effect of war on happiness.

1) Civil Wars: Violent conflict has the tangible effects mentioned above and, in addition, intangible effects in terms of psychic costs such as pain, suffering, fear, and agony, as well as empathy with relatives, friends and other persons mourning the victims. In a study comprising 44 countries around the year 2000, and using average happiness by country from representative surveys, Welsch (2008: 336) finds that the current number of conflicts significantly reduces the wellbeing of the population. He calculates that, on average, the compensating variation for one fatality is about 108,000 US dollars. This means that income must increase by 108,000 dollars to leave happiness constant when one additional person dies. The direct effects in terms of suffering, fear and agony are larger than the indirect effects due to the smaller income brought about by the premature death.

2) Terrorism: Terrorism is a special type of war in which, normally, the civil population is targeted and the goal is to create havoc and produce fear (see e.g. Frey 2004, Sandler and Enders 2004). Estimating standard happiness functions for two countries affected by terrorism, Frey, Luechinger and Stutzer (2007) show for France and Northern Ireland that more intensive terrorist activity in terms of the number of attacks and of victims significantly reduces the life satisfaction of the population. For Northern Ireland, the wellbeing cost from one additional terror victim amounts to about 0.6 per cent of income. This figure is similar to the one calculated by Welsch (2008: 335) for Israel, Burundi and Liberia.

3) Particular events and countries: The exposure of concentration camp inmates leads to intense distress due to the terrible experience but is sometimes alloyed with positive experience a former inmate may have later in life. In a careful study, Shmotkin and Lomranz (1998: 152-3) find that "... the survivors (are) deficient in satisfaction and joy... (but there is) also a dynamic response to challenge and change... leading to a life story that bears a message of comfort besides agony".

Another study (Landau, Beit-Hallahmi and Levy 1998) looks at life satisfaction in Israel in the period 1967 to 1979, during which time there were several wars, including the War of Attrition with Egypt, the October 1973 War, and the Israeli invasion of Lebanon. There were also many other war-like events, including terrorist attacks. As a result, "...wars, as well as attacks on civilians, significantly increase the levels of anxiety and fear in the population" (p. 330). Overall, the study concludes that national stress negatively affects happiness (pp. 348-350) but notes that this finding cannot necessarily be generalized for other countries and periods.

While these research results are revealing, they are incomplete: we have little systematic and empirically compelling evidence on how war affects happiness. The next three sections focus on three claims that play a crucial role for analyzing the relationship between war, peace and happiness.

\section{Claim: 'War brings happiness'}

At first sight, this claim seems to be outrageous. However, observers (e.g. Hedges 2002) have noted that some people who experience war find it energizing and even addictive. This may help to explain why many wars drag on and are still supported by the population though 
defeat is almost certain ${ }^{5}$. In order to be able to survive in wars, solidarity, trust and friendship play a large role. Such feelings tend to raise wellbeing (for the case of trust see Helliwell 2007, Layard 2005).

War also raises (affective) happiness in a more direct way, by the production of what has been termed 'combat flow'. "Such absorption is often reported in combat situations in which it contributes both to the well-being and to the efficiency of soldiers" (Harari 2008: 253). For the Vietnam War "addiction to the experience of combat flow"(p. 255) has been documented, but there is also evidence going back to Homeric Greece and medieval Europe. Noted authors such as Tolstoy in War and Peace (1865-68) for the Napoleonic period and Jünger in his book In Stahlgewittern (1920) for World War I extensively report instances of combat flow.

How should we deal with these forms of happiness in war? One solution could be to dismiss such feelings as inappropriate for moral reasons and to disregard them completely. Such a solution is in line with what many classical Greek philosophers thought. Epicurus is an example: “Though pleasure was a good in Epicures' view, it was always subordinate to the greater goal of achieving peace (ataraxia), a self-sufficient state free of anxiety and unease" (McMahon 2006: 209-10). Similar ideas can be attributed to Socrates, Plato and Aristotle with their notion of 'eudaimonia'. To totally neglect these forms of happiness experienced in war is, however, a drastic solution not taking into account well-documented feelings of happiness because they are illegitimate.

Harari (2008: 257) proposes to differentiate between sensual pleasures such as combat flow from the summum bonum of real wellbeing. Subjective feelings are not always a good indicator of what can be taken to be 'true' happiness. Moreover, waging war can certainly not be justified by an army of happy soldiers high on combat flow. Obviously, the wellbeing of the relatively small number of happy soldiers must be compared to the unhappiness of the large number of negatively affected civilians and unhappy soldiers.

\section{Claim: 'People adjust to wars'}

One of the major results of empirical happiness research is that people adjust to some extent to good and bad experiences (e.g. Frey and Stutzer 2002a, 2002b, Frey 2008). There is a tendency to return to a 'set point' of happiness determined by genetic factors. It must, however, be taken into account that the speed and extent of adjustment varies between areas and persons. For example, men do not adjust to being unemployed while women do (e.g. extensively Clark, Georgellis and Sanfey 2001). The question is whether people really adjust to war experiences. The finding that the change in the number of victims, rather than their absolute number, reduces wellbeing in civil wars suggests that there is some, but no complete, adaptation to the conditions of conflict (Welsch 2008: 334). But there does not seem to be any evidence for other forms of war. It is likely that people get used to some extent to the horrors of war. When one experiences that many persons die, then the fact that one's son, husband, father or other relative has died may be more bearable because the people affected are aware that they are no exception, and that other persons have had to come to terms with similar grief. On the other hand, one can well argue that experiencing the death of many others has a cumulative negative effect on one's own happiness. The question therefore remains open.

\footnotetext{
${ }^{5}$ It must be emphasized that the military and political leadership are often responsible for extending the duration of wars. A striking example is World War II where Hitler and the Nazi establishment prolonged the war by many months though defeat was clear and predicted by some generals such as Rommel as well as the rebels of 20 July 1944.
} 
How should we deal with this kind of reduction of unhappiness? Should we take war to be less brutal and devastating because people partly adjust to its horrors? This is a quite general question relating to all kinds of adjustments. Frederick and Loewenstein (1999: 320) conclude after an extensive and careful study of adaptation:

Would (people) stop wearing seatbelts with the assurance that they would get used to being paralyzed? Would they exploit an embezzlement opportunity knowing that prison wouldn't be all that bad in the long run? We suspect not. ${ }^{6}$

However, the fact is that adaptation to such events is never complete - as even the founders of set-point theory have now agreed (see e.g. Diener et al., 2009, 103-8). In the case of war, it seems to me that few people would wish to accept going to war because they know that they will get used to the immense sufferings. However, to ignore the process of adaptation is no convincing solution either, because ignoring it conflicts with empirical observations.

\section{Claim: 'The happiness of the dead is irrelevant'}

How should we treat those persons who die in war and therefore are no longer a living part of society? This is a philosophical issue I cannot judge. Three solutions come to mind:

The first is to disregard the wellbeing of the dead. This is done if the happiness of people is measured by representative surveys, i.e. the most frequently used approach (see e.g. the World Values Survey or the Gallup World Survey of Happiness). Disregarding the dead would not matter if the dead had the same average happiness level as the rest of the population. But this is exactly what is unknown; the dead may well be persons with a particularly high or low happiness potential in the future.

Two aspects seem to me to be relevant. Why should we disregard the happiness of those who died but count the wellbeing of those wounded, some of whom are closer to death than to life? Moreover, during wars many babies will not be born who, under peaceful conditions, would have come to life. If we regard the wellbeing of the dead we should (probably) also consider the happiness not gained by the unborn babies. To calculate the expected future happiness of unborn babies is difficult. One might take the average happiness of the respective generation of persons living (though this evidence will be available only in the future) and attribute it to the unborn babies. For example, if mostly highly pessimistic persons chose not to have babies during a war, those respective babies must be expected to be less happy during their lifetime because pessimism is a characteristic depressing happiness. As a result, the lifetime happiness of the unborn babies is overestimated. It follows that not to have these babies born raises the average happiness of the population, and to that extent war is less horrific.

The second solution is to just assume that the happiness of the dead is zero. This is, of course, a strong assumption but probably is considered reasonable by many people. When the wellbeing of a country is measured by taking the average self-reported subjective happiness score multiplied by average length of life (see e.g. Veenhoven 1999) this is indeed assumed.

The third solution would be to calculate the happiness the dead would have experienced if they were still alive. The respective techniques may be derived from econometric microstudies. One would first have to empirically estimate the future happiness based on the characteristics of a person such as his or her age, socio-economic background, education, health, expected length of life, etc. In a second step one would have to associate these characteristics to the persons who died in war. This is obviously a difficult procedure and may result in major mistakes. In particular, if the dead, say young soldiers killed on the battlefield,

\footnotetext{
${ }^{6}$ See also Fleurbaey 2009: 1060-61
} 
have characteristics not captured by the happiness function estimated, the estimates may be seriously biased. For example, the soldiers killed might have been more than averagely optimistic and idealistic. As these characteristics are positively related to happiness, a standard empirical approach would systematically underestimate the calculated future happiness of the soldiers killed. War then appears to be less damaging to happiness than it is in reality but only under the maintained, and probably false, assumption that soldiers are on average more optimistic and idealistic.

These considerations reveal that to calculate the presumed happiness of the dead and unborn babies is most questionable. Moreover, it makes happiness considerations even more speculative than they presently are.

Considering the grief, suffering and mourning of spouses, parents, children, other relatives and friends of the people who died can capture only one part of the unhappiness created by war. It must be emphasized that this does not account for the loss of happiness of the dead persons themselves. It may well be imagined that grief about a departed is immense to other persons, but that the person himself or herself wanted to die because he or she did not expect any happiness in the future.

Empirical estimates led to the conclusion that "The largest emotional losses are from the death of a spouse; the second-worst in severity are the losses from the death of a child; the third-worst is the death of a parent" (Oswald and Powdthavee 2008: 1). Based on an 'economistic' approach of valuing psychic effects, the loss of happiness by other persons has been found to be very large indeed: “... the hedonic compensation annual amount in the first year for the death of a child might be of the order of $£ 100,000 / \$ 200,000 "$ (Oswald and Powdthavee 2008: 19). And the grief continues for many years. The authors find that people do adapt to the loss of a loved one. The question is again whether such adjustment is quicker during wars in which many other people die.

\section{Conclusions}

This paper leaves a great number of questions open. As mentioned at the beginning, I focus on the question of how much, if at all, peace raises the happiness of the population. Broader and certainly also important aspects, such as that cooperation is better than conflict and therefore leads to a happier population, are not further pursued here for reasons of space.

War and peace have a large number of direct and indirect effects on happiness, difficult or impossible to capture. I am well aware that I have discussed only a limited part of them. In addition there are many problems due to issues of causality and attribution, making it very difficult to reach any empirical insights into the effects of war on happiness.

The paper concentrates on three fundamental claims regarding the effect of war and peace on happiness. These claims are: 'War brings happiness'; 'People adjust to wars'; and 'The happiness of the dead is irrelevant'. These claims are critically discussed and it is argued that they are open to doubt, but that there are some aspects of war contributing to people's happiness. An attempt is made to discuss different solutions to deal with these claims but it was made clear that each one has grave disadvantages.

I am surprised how little is known in the scholarly literature about the effect of war and peace on happiness - at least compared to the great advances made over the last few years with respect to the determinants of happiness under 'normal' conditions. While the results of this paper are extremely tentative, one goal of the paper has been reached if it draws attention to a missing and most important aspect of happiness research. 
Taken overall, and taking account of all the uncertainties mentioned, I conclude that Bruder Klaus was right in advising politicians and citizens not to extend the boundaries too far, not to interfere in the affairs of other countries, and most importantly, to keep peace. In these fundamental respects, this person living in the Alps as a hermit in the fifteenth century was truly wise. After considering what I have read and thought about while preparing this paper my personal conviction is unshaken: war is horrific, and all effort should be made to prevent it and this not only for moral reasons but also to raise the happiness of mankind.

\section{Acknowledgements}

I am grateful for helpful suggestions for improvement to Reto Cueni, Lisa Elsasser, John F. Helliwell, Margit Osterloh, Stephan Kyburz and Lasse Steiner.

\section{Author}

Bruno S. Frey

University of Zurich and University of Warwick

bruno.frey@econ.uzh.ch

\section{Publishing Timeline}

Received 8 February 2011

Accepted 5 April 2011

Published 20 July 2011

\section{References}

Clark, A. E., P. Frijters and M. A. Shields (2008) ‘Relative Income, Happiness, and Utility: An Explanation for the Easterlin Paradox and Other Puzzles', Journal of Economic Literature 46(1): 95-144. http://dx.doi.org/10.1257/jel.46.1.95

Clark, A. E., Y. Georgellis and P. Sanfey (2001) 'Scarring the psychological impact of past unemployment', Economica 68(270): 221-242. http://dx.doi.org/10.1111/1468-0335.00243

Collier, P. (1999) ‘On the Economic Consequences of Civil War', Oxford Economic Papers 51: 168-183. http://dx.doi.org/10.1093/oep/51.1.168

Collier, P. and A. Hoeffler (2003) 'Military Spending in Post-Conflict Societies', Mimeo, Centre for the Study of African Economies, Oxford.

Diener, E. and W. Tov (2007) 'Subjective Well-Being and Peace', Annals of Social Issues 63: 421-440. http://dx.doi.org/10.1111/j.1540-4560.2007.00517.x

Diener, E., R. Lucas, U. Schimmack and J. F. Helliwell (2009) Well-Being for Public Policy. Oxford and New York: Oxford University Press.

Dolan, P., T. Peasgood and M. White (2008) ‘Do we really know what makes us happy? A review of the economic literature on the factors associated with subjective well-being', Journal of Economic Psychology 29: 94-122. http://dx.doi.org/10.1016/j.joep.2007.09.001

Dorn, D., J. A. V. Fischer, G. Kirchgässner and A. Sousa-Poza (2005) 'Is it culture or democracy? The impact of democracy and culture on happiness', Social Indicators Research 82: 505-526. http://dx.doi.org/10.1007/s11205-006-9048-4

Fleurbaey, M. (2009) ‘Beyond GDP: The Quest for a Measure of Social Welfare’, Journal of Economic Literature 47: 1029-1075. http://dx.doi.org/10.1257/jel.47.4.1029

Frederick, S. and G. Loewenstein (1999) Hedonic Adaptation. In Diener, E. Kahneman, D. and Schwarz, N. (Eds.). Well-being: The foundations of hedonic psychology. Russell Sage Foundation.

Frey, B. (2004) S. Dealing with Terrorism: Stick or Carrot? Cheltenham, UK and Northampton, MA: Edward Elgar Publishing Limited.

Frey, B. S. (2008) Happiness: A Revolution in Economics. Cambridge, MA and London, England: The MIT Press. 
Frey, B. S., M. Benz and A. Stutzer (2004) 'Introducing Procedural Utility: Not Only What, but Also How Matters', Journal of Institutional and Theoretical Economics 160: 377-401. http://dx.doi.org/10.1628/0932456041960560

Frey, B. S., S. Lüchinger and A. Stutzer (2007) 'Calculating Tragedy: Assessing the Costs of Terrorism', Journal of Economic Surveys 21(1): 1-24. http://dx.doi.org/10.1111/j.1467-6419.2007.00505.x

Frey, B. S. and A. Stutzer (2000) 'Happiness Prospers in Democracy', Journal of Happiness Studies 1: 79-102. http://dx.doi.org/10.1023/A:1010028211269

Frey, B. S. and A. Stutzer (2002a) Happiness and Economics: How the Economy and Institutions Affect Human Well-Being. Princeton and Oxford: Princeton University Press.

Frey, B. S. and A. Stutzer (2002b) 'The Economics of Happiness', World Economics 3(1): 25-41.

Graham, C. and S. Sukhtankar (2004) 'Does Economic Crisis Reduce Support for Markets and Democracy in Latin America? Some Evidence from Surveys of Public Opinion and Well-being', Journal of Latin American Studies 36: 349-377. http://dx.doi.org/10.1017/S0022216X0400745X

Harari, Y. N. (2008) 'Combat flow: Military, political, and ethical dimensions of subjective well-being in war', Review of General Psychology 12: 253-264. http://dx.doi.org/10.1037/1089-2680.12.3.253

Hedges, C. (2002) War Is a Force That Gives Us Meaning. New York: Anchor Books.

Helliwell, J. F. (2007) 'Well-being and social capital: does suicide pose a puzzle?', Social Indicators Research 81: 455-496.

Helliwell, J. F. (2011) Institutions as Enablers of Well-Being: The Singapore Prison Case. International Journal of Wellbeing, 1 (2): 65-75.

Helliwell, J. F. and C. Barrington-Leigh (2010) 'Measuring and Understanding Subjective Well-Being', Canadian Journal of Economics 43: 729-753.

Helliwell, J. F. and S. Wang (2011) 'Trust and Well-Being', International Journal of Well-Being 1: 42-78.

Inglehart, R. and H-D. Klingemann (2000) Genes, Culture and Happiness. Cambridge: MIT Press.

Iqbal, Z. (2006) 'Health and Human Security: The Public Health Impact of Violent Conflict', International Studies Quarterly 50: 631-649. http://dx.doi.org/10.1111/j.1468-2478.2006.00417.x

Jünger, E. (2007 [1920]) In Stahlgewittern. Stuttgart: Klett-Cotta.

Kahneman, D., P. P. Wakker and R. Sarin (1997) 'Back to Bentham? Explorations of Experienced Utility', The Quarterly Journal of Economics 112(2): 375-405. http://dx.doi.org/10.1162/003355397555235

Koubi, V. (2005) 'War and Economic Performance', Journal of Peace Research 42(1): 67-82. http://dx.doi.org/10.1177/0022343305049667

Landau, S. F., B. Beit-Hallahmi and S. Levy (1998) ‘The Personal and the Political: Israelis' Perception of Well-Being in Times of War and Peace', Social Indicators Research 44: 329-365. http://dx.doi.org/10.1023/A:1006885502825

Layard, R. (2005) Happiness: Lessons from a New Science. London and New York: Penguin.

McMahon, D. M. (2006) Happiness: A History. New York: Atlantic Monthly Press.

Murdoch, J. C. and T. Sandler (2002) 'Economic Growth, Civil Wars, and Spatial Spillovers', Journal of Conflict Resolution 46: 91-110.

Organski, A. F. K. and J. Kugler (1980) The War Ledger. Chicago: University of Chicago Press.

Oswald, A. J. and N. Powdthavee (2008) 'Death, Happiness, and the Calculation of Compensatory Damages', Journal of Legal Studies 37 (2008), S217-S252. http://dx.doi.org/10.1086/595674

Sandler, T. and W. Enders (2004) 'An economic perspective on transnational terrorism', European Journal of Political Economy 20 (2): 301-316. http://dx.doi.org/10.1016/j.ejpoleco.2003.12.007

Shmotkin, D. and J. Lomranz (1998) 'Subjective Well-Being Among Holocaust Survivors: An Examination of Overlooked Differentiations', Journal of Personality and Social Psychology 75(1): 141155. http://dx.doi.org/10.1037/0022-3514.75.1.141

Tolstoy, L. (1982 [1865-68]) War and Peace. London: Penguin.

Veenhoven, R. (1999) 'Quality of Life in Individualistic Societies: A Comparison in 43 Nations in the Early 1990s', Social Indicators Research 48: 159-188. http://dx.doi.org/10.1023/A:1006923418502

Welsch, H. (2008) 'The Social Cost of Civil Conflict: Essays from Surveys of Happiness', Kyklos 61: 320340. http://dx.doi.org/10.1111/j.1467-6435.2008.00404.x 